\title{
COMMENTS
}

\section{RETAIL GASOLINE FRANCHISE TERMINATIONS AND NONRENEWALS UNDER TITLE I OF THE PETROLEUM MARKETING PRACTICES ACT}

Only since World War II has franchising becoine a distinct method of inarketing. ${ }^{1}$. Although franchise law is now recognized as a separate entity, ${ }^{2}$ the dimensions of this area of the law remain unclear. "Business franchises enjoy an elusive status because they involve aspects of sales, agency, lease, license, tradeinark, employment, and joint venture." 3 The fact that franchise law draws on so inany different aspects of the law, yet does not fit completely into any one area, has led soine commentators to suggest that franchising is "sui generis." 4 Accordingly, legal precedents froin contract or tradeinark law alone may be of only limited utility in analyzing franchise problems. Instead, resolution of franchise disputes frequently depends upon judicial adapta-

THE FOLLOWING CITATIONS WILL BE USED IN THIS COMMENT:

H.R. REP. No. 161, 95th Cong., 1st Sess. (1977) [hereinafter cited as H.R. REP. No. 161];

Proposed Petroleum Marketing Practices Act: Hcarings on H.R. 130 Before the Subcomm. on Energy and Power of the House Comm. on Interstate and Foreign Commerce, 95th Cong., 1st Sess. (1977) [hereinafter cited as Hearings];

Brown, Franchising-A Fiduciary Relationship, 49 TEx. L. Rev. 650 (1971) [hereinafter cited as Brown];

Jordan, Unconscionability at the Gas Station, 62 MINN. L. Rev. 813 (1978) [hereinafter cited as Jordan].

1. Brown 650 .

2. See, e.g., Title 1 of Petroleum Marketing Practices Act, 15 U.S.C.A. $\$ \S 2801-2806$ (West Supp. 1979) (also known as the "Dealers' Day in Court Act"). This Act is the latest step in the movement toward recognizing franchising as a unique branch of the law. The Automobile Dealers' Day in Court Act, 15 U.S.C. $\$ \S 1221-1225$ (1976), brought franchise regulation to the federal level for the first time. See generally Note, Hope Yet for the Automobile Dealers' Day in Court Act: Marquis v. Chrysler Corp., 1979 DUKE L.J. 1185. In addition, most states have adopted some type of franchise regulation legislation, and at least 30 states now specifically regulate oil franchises to some degree. Hearings 227 (stateinent of D.R. Martin).

3. Note, Constitutional Obstacles to State "Good Cause" Restrictions on Franchise Terminations, 74 CoLUM. L. Rev. 1487, 1488 (1974).

4. Note, Regulation of Franchising, 59 MINN. L. REv. 1027, 1029 (1975); see Brown 663-64; Note, A Sui Generis Approach to Franchise Termination, 50 Notre Dame Law. 545 (1975). 
tions of other legal doctrines, or upon legislative directives.

In recent years, much of the development in franchising law has been in the area of franchise relationships between petroleum product suppliers and dealers. Courts and legislatures have placed particular emphasis on preventing petroleun product suppliers from arbitrarily and unjustly terminating their retail gasoline franchisees. ${ }^{5}$ Numerous states have passed statutes that prohibit an oil franchisor from terminating a dealer-franchisee without "good cause."6 In 1978, after five years of debate, Congress passed the Petroleum Marketing Practices Act (the Act). ${ }^{7}$ Title I of the Act $^{8}$ federalizes the law of oil franchise regulation and prohibits an oil franchisor from terminatimg or failing to renew a dealer-franchisee except for narrowly defined "good cause."9 The Act also creates a private cause of action for gasoline station dealers who believe their franchises have been unjustly terminated. ${ }^{10}$ The passage of the Act could affect not only the relationship between oil compames and their service station dealers, but also consumers through changes in gasoline prices and the quality of dealer service. The Act's passage also adds another variable to the increasingly complicated national energy situation. This Comment will explore the problems addressed by this legislation and analyze the solutions the statute offers. The Comment will then discuss possible sources of conflict between the Act and other laws and set forth a framework for judicial reconciliation

5. In the vast majority of retail oil franchises, the franchisor is a major oil company. Franchise termimation legislation is aimed primarily at these companies, because of their clear economic superiority over retail station franchisees. Nevertheless, in the recently enacted Petroleum Marketing Practices Act, 15 U.S.C.A. $\$ \S 2801-2806$ (West Supp. 1979), Congress refused to accept an amendment that would have exempted small oil suppliers from the Act's provisions. Congress apparently adopted the view that "[i]t makes little difference whether the supplier is a jobber or a major oil company. The relationship is the same. A shot from a 22 may be just as lethal as a shot from a 45." Hearings 128 (statement of Charles L. Binsted).

6. See, e.g., CAL. Bus. \& Prof. Code $\$ \S 20999-20999.3$ (West Supp. 1979); GA. Code ANN. $\S \S 106-1101$ to -1112 (Supp. 1977); N.Y. GEN. Bus. LAw § 199-a to -j (McKinney Supp. 1978). Other states protect franchised gasoline dealers through general franchise statutes. See, e.g., Conn, Gen. STat. AnN. $§ \S 42-133$ e to -133g (West Supp. 1979); Del. Code tit. 6, $\S \S 2551-2556$ (1974); N.J. STAT. ANN. $\S \S 56: 10-1$ to -12 (West Supp. 1979).

7. Pub. L. No. $95-297,92$ Stat. 322 (1978) (codified at 15 U.S.C.A. $\S \S 2801-2841$ (West Supp. 1979)).

8. 15 U.S.C.A. $\$ \$ 2801-2806$ (West Supp. 1979). Title II, which deals with octane ratings, and Title III, which deals with motor fuels subsidization, are outside the scope of this Comment. All references to the Petroleum Marketing Practices Act or to "the Act" pertain only to Title I.

9. Id. $\$ 2802$. The legislative history of the Act reveals that Title I was designed to establish "minimum federal standards governing the termination and non-renewal of franchise relationships for sale of motor fuel by the franchisor or supplier of such fuel .... Title I establishes protection for franchisees froin arbitrary or discriminatory termmations or non-renewal of franchises." S. REP. No. 731, 95th Cong., 2d Sess. 15, reprinted in [1978] U.S. CODE CoNG. \& AD. NEws 873.

10. 15 U.S.C.A. $\S 2805$ (West Supp. 1979). 
of these competing interests. Finally, the commercial setting of the franchise relationship will be analyzed to determine the relevance of economic and business variables to the resolution of franchise termination disputes under the Act.

\section{The Impetus for Passage of the Petroleum Marketing PRACTICES ACT}

\section{A. The Need for Regulation and the Justification Supplied by Franchise Theory.}

The Petroleum Marketing Practices Act addresses the problem of unjust termination of gasoline dealership franchises by suppliers. The passage of the Act was the culinmation of a progression of events that began in the mid-1960s. First, commentators focused their attention on the problein of unjust franchise termination." Next, coinmentators and some courts began to regard the franchise relationship as a "joint venture" 12 in whicli both parties to the franchise had a duty to treat each other fairly. Third, otlier commentators and courts adopted the view that a franchisor is a fiduciary to the franchisee, so that the franchisor may not terminate the franchisee without "good cause."13 Fimally, many states, implicitly adopting the "fiduciary" model of the franchise, passed franchise termination statutes, thereby precipitating the call for a federal franchise termination act. ${ }^{14}$ A full understanding of the purposes and effect of the Petroleuin Marketing Practices Act requires an awareness of these developments, and an understanding of the characteristics of gasoline franchises.

In a typical oil franchise arrangement the franchisor, usually a major oil coinpany, enters into a franchise relationship with a local dealer. The franchisor owns the land upon which the service station rests; a lease of the land is part of the franchise arrangement. These leases set a high minimum rent supplemented by a payment based on the number of gallons of gasoline sold by the dealer. ${ }^{15}$ In addition, the franchisor may set "minimum gallonage" requirements that increase as sales increase. An increase in sales in any given month will thus force the franchisee to sell even more in the following month. ${ }^{16}$

In addition to these monetary aspects of the oil franchise relation-

I1. See, e.g., Gellhorn, Limitations on Contract Termination Rights-Franchise Cancellations, I967 DUKE L.J. 465.

12. See text accompanying notes $26-29$ infra.

13. See note 30 infra and accompanying text.

I4. See notes 32-34 infra and accompanying text.

15. Brown 656.

16. See, e.g., Malone v. Crown Cent. Petroleuin Corp., 474 F. Supp. 306 (D. Md. 1979). 
ship, other provisions may cause difficulties for franchisees. The franchisee may be required to stay open twenty-four hours per day, even when this practice is unprofitable. ${ }^{17}$ Similarly, the franchisee may be forced to participate in prize games and to buy tires, batteries, and accessories from the oil suppler at inflated rates. Requirements like these can reduce the dealer's already slim profit margin. ${ }^{18}$

Oil franchise agreements generally allow immediate termination of the relationship by the oil company if the agreement's requirements are not fully met by the dealer. The combination of financial hardship, onerous franchise requirements, and ease of termination may explaim the very high attrition rate among dealers in the past. ${ }^{19}$

In response to the criticism that the oil franchise relationship was unfair to the dealer-franchisee, the oil companies pointed out that the typical oil franchise offers the franchisee an opportunity to enter a profitable business with a relatively small amount of capital. The franchisor has already purchased the land and equipment, and may even finance a large portion of the dealer's imitial investment costs. In addition, the franchisee receives extensive training, a credit card system, and the established trade of the oil company in return for his investment. ${ }^{20}$ Oil companies also argued that abuses by franchisors were unlikely because dealers who are satisfied with the franchise relationship are likely to be more productive. ${ }^{21}$ Furthermore, an oil company that terminates dealers without sufficient cause loses the time and money it has invested in the franchise relationship. Thus, it may be in the oil company's interest to form a "long, harmonious relationship" with its dealers. ${ }^{22}$

Prior to the passage of the Act most conimentators rejected the oil companies' arguments and concluded that the typical oil franchise relationship was unfair to the dealer-franchisee. Professor Harold Brown, the leading scholar in the field of franchise law, put it this way:

In the Nation's second largest industry, the major oil firms have the gasoline station dealers in virtual bondage, hinged on the constant threat that their short-term contracts will not be renewed unless they submit to burdensome franchisor-imposed practices . . . . It is generally conceded that the gasoline station situation is alinost hopeless

17. See, e.g., Arnott v. American Oil Co., 609 F.2d 873, 877 (8th Cir. 1979), cert. denied, 48 U.S.L.W. 3693 (U.S. Apr. 29, 1980).

18. Brown 657.

19. In 1975 it was reported that "the annual turnover of gas station dealers based on insolvency, terminations, and failure to renew varies from 25-40\%." Note, A Sui Generis Approach, supra note 4, at 546.

20. Jordan 819-20.

21. Id.

22. Id. 820-21. 
and offers a prime example of the worst abuses in franchising . . . . [T] he major oil companies have proven almost impervious to attack. ${ }^{23}$

In the past, the franchisee could find some legal relief through contract $^{24}$ or antitrust ${ }^{25}$ actions, but these methods proved unsatisfactory in

23. Brown 655-57. See also FTC v. Texaco Inc., 393 U.S. 223, 226-27 (1968) (recognizing the economic dominance of the oil company in a franchise relationship); Shell Oil Co. v. Marinello, 63 N.J. 402, 307 A.2d 598 (1973), cert. denied, 415 U.S. 920 (1974). In Marinello, the court read an implied "good cause" termination clause into an oil franchise agreement. In so holding, the court took notice of the greatly superior economic position of Shell vis-a-vis its franchisee. 63 N.J. at 408,307 A.2d at 601.

The hue and cry over the oil franchisors' dominance of the franchise relationship reached new heights when the president of the National Congress of Petroleum Retailers analogized the franchisees' situation to slavery: "Gentlemen, those of you who watched 'Roots' on TV will understand when I say, "the franchisees] want to leave the plantation.' " Hearings 127 (statement of Charles R. Matties).

24. Prior to the enactment of state legislation that explicitly set out a "good cause" standard for franchise termination, courts were reluctant to inply this standard into franchise agreements. Courts relied instead on basic contract law to hold that "terminable at will" clauses were valid since the parties had freely bargained for them. See, e.g., Goldinger v. Boron Oil Co., 375 F. Supp. 400 (W.D. Pa. 1974), aff'd, 511 F.2d 1393 (3d Cir. 1975); Russell v. Shell Oil Co., 382 F. Supp. 395 (E.D. Micl.), affd, 497 F.2d 924 (6tl Cir. 1974); North Penn Oil \& Tire Co. v. Phillips Petroleum Co., 371 F. Supp. 676 (E.D. Pa. 1974). Historically, contract law has proved to be an inadequate remedy for unjust terminations. See Note, Termination of Franchise Without Good Cause Is Void as Against Public Policy, 45 Miss. L.J. 252, 257 (1974) (freedom to contract is an illusion in the franchise setting). Recently, however, courts havc begun to use the unconscionability doctrine to give franclisees relief from termmation clauses. See, e.g., Shell Oil Co. v. Marinello, 63 N.J. 402, 307 A.2d 598 (1973), cert. denied, 415 U.S. 920 (1974); Ashland Oil, Inc. v. Donahue, 223 S.E. 2d 433 (W. Va. 1976). See text accompanying notes 114-34 infra.

25. Gasoline dealer franchise termmations and nonrenewals frequently raise antitrust issues. Franclisees may argue that the terms of the agreement whose breach gave grounds for the termination violate the antitrust laws, or that threats of termmation or nonrenewal were used to coerce participation in an illegal agreement. For example, franchisees nay contend that the supplier tried to fix the retail price of gasoline. Agreements between buyers and sellers fixing the buyers' resale prices are illegal per se under section 1 of the Sherman Act. Dr. Miles Medical Co. v. John D. Park \& Sons Co., 220 U.S. 373 (1911). Resale price fixing may also be illegal in consignment arrangments. See Simpson v. Union Oil Co., 377 U.S. 13 (1964). But see United States v. General Elec. Co., 272 U.S. 476 (1926) (Dr. Miles not applicable to a consigninent arrangement). Arnott v. American Oil Co., 609 F.2d 873 (8th Cir. 1979), cert. denied, 48 U.S.L.W. 3693 (U.S. Apr. 29, 1980), offers an example of this problem in a gasoline franchise. The franchisee contended that the franchisor had violated section 1 by dictating maxinum retail prices and by enforcing the price scheme in threatening to terminate the agreement if the franchisee resisted. The Eighth Circuit found evidence of a coinbimation that was sufficient to invoke the per se rule against resale price maintenance. 609 F.2d at 885 . The court relied on Albrecht v. Herald Co., 390 U.S. 145 (1968), which extended the Dr. Miles rule to agreenents setting maximum prices. 609 F.2d at 885 . Judge Bright, lowever, found insufficient evidence of a conspiracy or combination. Id. at 891-93 (Bright, J., concurring and dissenting). Judge Bright also suggested, but did not decide, that the per se rule for maximum resale price mamtenance might survive in light of Continental T.V., Inc. v. GTE Sylvania, Inc., 433 U.S. 36 (1977). 609 F.2d at 891 n.6 (Bright, J., concurring and dissenting). Sy/vania restored the "rule of reason" approach to analysis of vertieal territorial restraints.

Franchisees may also allege that a termination or nonrenewal constitutes an illegal refusal to deal. Franchisors enjoy a right to refuse to deal under the doctrime of United States v. Colgate \& Co., 250 U.S. 300 (1919), but this doctrime is narrowly defined. 
resolving termination disputes. In response to these problems, a new legal theory developed that offered the franchisee sigmificant protection from unjust terminations. This new approach sought to dispel the notion that a franchise can be analyzed through the use of a traditional contract model. ${ }^{26}$ A franchise is now viewed as a "joint venture"27 in which the franchisor and the franchisee have a duty to treat each other fairly. As a result, "important legal consequences flow from the judicial determination that an agreement is a franchise rather than another type of contract."28

The jomt venture theory is premised on the idea that both parties to a franchise contribute to the overall viability and profitability of the business. The franchisor provides a recognized trademark and products, while the franchisee, through good service to the public, generates goodwill and profits for the franchisor. Thus, between the franchisor and franchisee, there are

mutual obligations of good faith, especially in the manner of their protecting the goodwill in the trademark .... While the franchisee necessarily places his faith and confidence in the franchisor, the latter may also be substantially reliant on each franchisee, not merely for its own interest, but also as guardian for the interests of the other franchisees in the system. ${ }^{29}$

In theory, then, the franchise relationship in the joint venture model is an integrated whole in which the respective parties work to-

[I]f a manufacturer seeks to achieve resale price maintenance or any other unlawful vertical restraint through the exercise of its right to refuse to deal and a prior announcement of policy, the manufacturer's conduct remains lawful only so long as no step in addition to announcement of policy and withdrawal of trade from violators is taken by the manufacturer. If a manufacturer sets up a policing mechanism to discover violators, if it reinstates violators upon declarations of their intent to comply in the future, the Colgate defense is gone.

L. Sullivan, Handbook of the Law of Antitrust 393 (1977) (footnotes omitted).

A third common source of antitrust claims by service station franchisees against gasoline franchisors arises frown "tying arrangements," in which the franchisor sells gasoline only if the franchisee agrees to purchase his tires, batteries, and accessories from the franchisor. Such an arrangement may be illegal under section 1 of the Sherman Act, 15 U.S.C. \$ 1 (1976), section 3 of the Clayton Act, id. § 14, or section 5 of the Federal Trade Commission Act, id. § 45 . See, e.g., Atlantic Ref. Co. v. FTC, 381 U.S. 357 (1965); Shell Oil Co. v. FTC, 360 F.2d 470 (5th Cir. 1966).

While the antitrust laws offer franchisees some relief from unjust terminations, they do so only in very specific situations where proof is likely to be difficult and the law unclear. Further, antitrust remedies are arguably deficient im providing the successful franchisee-plaintiff only with damages and not with the imjunctive relief that would restore his service station to him. Finally, antitrust actions are too time-consuming and costly for the typical oil franchisee. See Note, Regulation of Franchising, supra note 4, at 1033-34. See generally Bohling, Franchise Terminations Under the Sherman Act: Populism and Relational Power, 53 TEx. L. REv. 1180 (1975).

26. See, e.g., Brown \& Cohen, Franchise Misuse, 48 Notre Dame LAw. 1145, 1163 (1973).

27. Id.

28. Note, supra note 24, at 257.

29. Brown \& Cohen, supra note 26 , at 1163. 
gether toward a common goal. As an offshoot of this joint venture theory, one commentator proposed that because franchisors enjoy strong control over the franchise relationship, they should be considered fiduciaries to their franchisees and thus be bound to protect the franchisees' position..$^{30}$

Application of these theoretical constructs to the termination situation produces "a requirement that a franchise cannot be terminated or subjected to a failure to renew unless the franchisor can sustain the burden of proving 'good cause.' "31 Good cause termination statutes are in part a result of this new theory of the franchise.

\section{B. State Statutory Response and the Call for Federal Legislation.}

At least thirty states responded to the need for a redefinition of the franchise relationship by passing some type of franchising statute. ${ }^{32}$ Solne of these statutes deal specifically with service station franchises, while the remainder are general franchise regulation acts that cover all franchise relationships. ${ }^{33}$ The typical state statute prohibits franchise

30. See generally Brown. Although courts have for some time recognized the economic superiority of the franchisor in the oil franchise relationship, see note 23 supra, only recently have they begun to accept explicitly the fiduciary model of franchising. In Arnott v. American Oil Co., 609 F.2d 873 (8th Cir. 1979), cert. denied, 48 U.S.L.W. 3693 (U.S. Apr. 29, 1980), the court stated:

[T] he dealer-oil company relationship has been the subject of much recent litigation, and the current trend of authority recognizes that a franchise relationship exists between a service station dealer and the oil company whose trademark the dealer is promoting. Inherent in a franchise relationship is a fiduciary duty.

609 F.2d at 881 (emphasis added).

The Arnot court concluded that the district court was correct in instructing the jury that a fiduciary relationship existed, making termmation proper only if "good cause" existed. Id. at 884. The court cited the South Dakota good cause ternination statute, S.D. CoMPILED LAWS ANN. \$ 37-5A-66(7) (1977), and the Petroleum Marketing Practices Act to support the fiduciary relationship theory, although the decision rested on neither statute smce the termination occurred prior to their passage. 609 F.2d at 883.

Professor Brown, the leading advocate of the fiduciary model, suggests that the following principles should govern the franchise relationship: (I) when one has power to control another, a fiduciary obligation exists; (2) a fiduciary's duty is coextensive with his power to control; and (3) when the power to control another is abused by preference of oneself, equity will intervene. Brown 664. See generally Atlantic Ref. Co. v. FTC, 381 U.S. 357 (1965) (upholding an FTC injunction prohibiting a franchisor from forcing its service station dealers to buy their tires from Goodyear, with whoin the franchisor had entered into a proinotional contract). See also FTC v. Texaco Inc., 393 U.S. 223 (1968); Simpson v. Union Oil Co., 377 U.S. 13 (1964).

31. Brown \& Cohen, supra note 26, at 1163; cf. Symposium, The Franchise RelationshipAbuses and Remedies, 33 OHIO ST. L.J. 641, 663-64 (I972) (arguing that the mutual fiduciary duty model of franchising is not workable, and proposing mandatory collective bargaining between the franchisor aud an agent representing all franchisees to secure fairness in the franchise agreement).

32. Hearings 227 (statement of D.R. Martin). While scholarly commentary played some role in the development of franchise legislation, the real impetus for regulation came from the service station franchisees, through their dealer organizations. See Jordan 856. See generally Hearings.

33. See note 2 supra. 
terminations without "good cause," regardless of the terms of the franchise contract. These statutes are a clear step toward acceptance of the fiduciary theory of franchising. ${ }^{34}$

Many franchisors have asserted that the state franchise statutes are unconstitutional in some respect. For example, franchisors defending against actions brought under these statutes have successfully asserted impairment of contract claims. ${ }^{35}$ They have argued with less success that the statutes are void for vagueness, ${ }^{36}$ unreasonably restrain interstate commerce, ${ }^{37}$ or violate due process. ${ }^{38}$

The desire to regulate terminations of all oil franchises led to proposals for a federal oil franchise statute. These proposals were supported by the major oil companies, who preferred a uniform federal regulation to fifty different state standards. ${ }^{39}$ Despite support from both oil companies and dealers for federal legislation, it took five years for Congress to pass the Petroleum Marketing Practices Act. ${ }^{40}$ This

34. See notes 26-31 supra and accompanying text.

35. See, e.g., Globe Liquor Co. v. Four Roses Distillers Co., 281 A.2d 19 (Del.), cert. denied, 404 U.S. 873 (1971), which held that the Delaware franchise termmation law is an unconstitutional impairment of contracts wheu applied to franchises existing before the effective date of the act:

We think the Delaware Franchise Security Law . . . makes a substantive change in the rights and obligations under this contract. Tliese substantive changes are the imposition on [the franchisor] of the obligation to deal with [the franclisee] imdefinitely and the imposition of a penalty . . . if [tle franchisor insists] on its contractual rights.

281 A.2d at 21. Cf. Phillips Petroleum Co. v. Paradee Oil Co., 343 A.2d 610, 61 I (Del. 1975) (Delaware franchise law does not unconstitutionally impair franchise contracts entered into after the effective date of the statute). See also Note, supra note 3, at 1499. Although the contract clause, U.S. CONST. art. $1, \S 10$, cl. 1 , does not limit federal legislation, impairment of contract may be a violation of the due process clause of the fiftl amendment. See generally Hocliman, The Supreme Court and the Constitutionality of Retroactive Legislation, 73 HARv. L. REv. 692 (1960).

36. See, e.g., Globe Liquor Co. v. Four Roses Distillers Co., 281 A.2d 19, 21 (Del.), cert. denied, 404 U.S. 873 (1971).

37. See, e.g., Westfield Centre Serv., Inc. v. Cities Serv. Oil Co., 158 N.J. Super. 455, 482-84, 386 A.2d 448, 463-64 (1978).

38. See, e.g., id. at 478-79, 386 A.2d at 459; Globe Liquor Co. v. Four Roses Distillers Co., 281 A.2d 19, 23 (Del.), cert. denied, 404 U.S. 873 (197I).

39. A Shell Oil Company executive put it this way:

This hodgepodge of state legislation thus far has greatly imcreased the administrative burden and expense of the supplier in conducting the relationships existing between him and his dealers and jobbers....

Shell is not opposed to federal legislation which would equitably regulate the distributor or dealer relationship, provided ... that sucl legislation ... preempts and takes precedence over all sucli controls which are not the same as the federal controls. Hearings 227 (statement of D.R. Martin). The Act does preempt state Iaw to the extent that it is inconsistent with the federal statute. 15 U.S.C.A. $\$ 2806$ (West Supp. 1979).

40. Begining in 1973 Cougress began to hold hearings and issue reports dealing with the problems of retail gasoline franchisees, but it was not until 1978 that the Petroleum Marketing Practices Act was finally passed. See Fair Marketing of Petroleum Products Act: Hearings on $S$. 1599 Before the Consumer Subcomm. of the Senate Comm. on Commerce, 93d Cong., Ist Sess. (1973); S. REP. No. 1071, 93d Cong., 2d Sess. (1974); Franchises Petroleum Dealers: Hearings on 
delay did, however, give the drafters of the Act the opportunity to observe the problems encountered by state franchise regulation statutes and to alter accordingly the approach of the Act.41

The legislative history of the Petroleun Marketing Practices Act reveals that Title I was passed to reduce the disparity in bargaining power between the oil franchisor and his franchisee. 42 Title I seeks to effectuate the "reasonable expectations of the parties to a motor fuel franchise [who believe] that the relationship will be a continuing

H.R. 16510 Before the Subcomm. on Communications and Power of the House Comm. on Interstate and Foreign Commerce, 93d Cong., 2d Sess. (1974); Fair Marketing of Petroleum Products Act: Hearings on S. 323 Before the Senate Comm. on Commerce, 94th Cong., 1st Sess. (1975); H.R. REP. No. 1615, 94th Cong., 2d Sess. (1976); H.R. ReP. No. 1762, 94th Cong., 2d Sess. (1976); Problems of Small Retail Petroleum Marketers: Hearings Before the Subcomm. on Energy and Environmemt of the House Comm. on Small Business, 94th Cong., 2d Sess. (1976); Petroleum Marketing Practices: Hearings on H.R. 13000 Before the Subcomm. on Energy and Power of the House Comm. on Interstate and Foreign Commerce, 94th Cong., 2d Sess. (1976); Petroleum Marketing Practices: Hearings on H.R. 130 Before the Subcomm. on Energy and Power of the House Comm. on Interstate and Foreign Commerce, 95th Cong., 1st Sess. (1977); Petroleum Marketing Practices Act: Hearings on S. 19 Before the Subcomm. on Energy Conservation and Regulation of the Senate Comm. on Energy and Natural Resources, 95th Cong., 1st Sess. (1977); Proposed Petroleum Marketing Practices Act: Hearings on H.R. 130 Before the Subcomm. on Energy and Power of the House Comm. on Interstate and Foreign Commerce, 95th Cong., 1st Sess. (1977); H.R. REp. No. 161; S. REP. No. 731, supra note 9; S. REP. No. 732, 95th Cong., 2d Sess. (1978).

41. For example, the drafters of the Act realized that subjecting pre-existing franchises to the termination provisions anounted to the unconstitutional taking of the franchisor's property without compensation. Agreements that existed prior to the Act's passage were exempted from the termination provisions of Title I, although failures to renew pre-existing relationships were brought within the statute's purview. 15 U.S.C.A. § 2802(a) (West Supp. 1979); see H.R. REP. No. 161, at 22. See also Frisard v. Texaco Inc., 460 F. Supp. 1094, 1098 (E.D. La. 1978).

Despite the drafters' efforts, the constitutionality of the Act remains an unresolved issue. One court interpreting a New Jersey franchise statute similar to the Act questioned whether the statute violated due process by forbidding a franchisor from terminating a franchisee in order to withdraw all his marketing operations froun the econounic region:

[I]t is arguable that to prohibit a franchisor from discontinuing all business within the state would . . . deprive the franchisor of liberty or property without due process of law .... And if an imposed obhigation to continue marketing in New Jersey is thought to be justified by the franchisor's election to grant or renew franchises in the state with knowledge of the statutory requirement, the doctrine of "unconstitutional conditions" may well be invoked against the statute.

Consumer Oil Corp. v. Phillips Petroleum Co., 488 F.2d 816, 819 (3d Cir. 1973). Although it did not reach the merits of the constitutional claims, the Consumer Oil court was persuaded that such claims "would not be frivolous." Id.

Although section 2802(b)(2)(E) of the Act does provide for terminations due to a withdrawal froin the economic region by the franchisor, see note 63 infro, the many conditions placed upon the franchisor before he may terminate under this section make it unclear whether the constitutional probleuns raised in Consumer Oil have been surmounted by the Act.

The Autounobile Dealers' Day in Court Act, 15 U.S.C. $\$ 1221$ (1976), which prohibits automobile franchise terminations without good cause, has withstood constitutional challenges based on due process, vagueness, and freedom to contract. Blenke Bros. v. Ford Motor Co., 203 F. Supp. 670, 672-73 (N.D. Ind. 1962).

42. H. R. REP. No. 161 , at $14-15$. 
one."43 The statute also attempts to avoid "the prospect of nonrenewal for arbitrary or discriminatory grounds [that] threatens the independence of the franchisee as a competitive influence in the rnarketplace."44

\section{The Provisions of the Petroleum Marketing Practices ACT}

The provisions of Title I of the Petroleum Marketing Practices Act ${ }^{45}$ have been described as "unusual, circuitous, and complex." 46 The coinplexity and detail of the statute are attributable at least in part to a desire to avoid the vagueness problems that plagued state "good cause" termination statutes. ${ }^{47}$ The result, however, is a statute that is difficult to interpret and understand. ${ }^{48}$

The first step in analyzing the Act is to understand the statute's definitions of "franchise" and "franchise relationship." The statute defines a "franchise" as an agreement between an oil supplier and an oil dealer in which the supplier permits the dealer to use the supplier's trademark in connection with the sale of notor fuel. ${ }^{49}$ The Act also treats the lease of the service station property to the dealer as part of the franchise. 50 The term "franchise relationship" is defined as "the respective motor fuel marketing or distribution obligations . . . of a franchisor and a franchisee which result from the marketing of motor fuel under a franchise."51 This statutory language recognizes that the "franchise relationship" extends beyond the bare bones of a contract or franchise agreement. ${ }^{52}$ Such a recogmition is sigmificant, as it demonstrates congressional acceptance of the fiduciary model of franchising..$^{53}$

43. Id. 15 .

44. Id. 16.

45. 15 U.S.C.A. $\$ \S 2801-2806$ (West Supp. 1979).

46. Gilderhus v. Amoco Oil Co., 470 F. Supp. 1302, 1303-04 (D. Minn. 1979).

47. See note 36 supra and accompanying text.

48. The language of the Act is so complicated that the statute itself requires that the Department of Energy publish a "simple and concise" summary of the remedies and obligations imposed. 15 U.S.C.A. $\$ 2804$ (d)(1) (West Supp. 1979). A franchisor wlio gives a termination notice to a franchisee is required to furnisls a copy of this summary to the dealer. Id. $\S 2803(c)(3)(C)$.

49. "The term 'franchise' means any contract . . . under whicls a refiner or distributor . . . authorizes . . . a retailer . . to use, in cormection with the sale . . of motor fuel, a trademark whicls is owned or confrolled by such refiner. . . " Id. § 2801(1)(A).

50. $I d$. $\S 2801(1)(\mathrm{B})(\mathrm{i})$.

51. Id. $\$ 2801(2)$.

52. "The concept of a franchise relationship is an important one . . because it is defined and treated under the PMPA, as an entity separate from the franchise, or contract." Frisard v. Texaco Inc., 460 F. Supp. 1094, 1098 (E.D. La. 1978).

53. See notes 26-31 supra and accompanying text. 


\section{A. Termination and Nonrenewal.}

Under the Petroleum Marketing Practices Act, franchisors seekmg to terminate a franchise ${ }^{54}$ must initiate the termination process by giving the franchisee notice at least ninety days prior to termination. ${ }^{55}$ Furthermore, a franchisor inust give notice of termination within 60 , 90 , or 120 days (depending on the reason) after he discovers or should discover the reason for terminating. ${ }^{56}$ This is to prevent the franchisor from renewing old eomplaimts against the franchisee as an excuse for termination. ${ }^{57}$

Notice is only the first requirement for termination under the Act. Having complied with the notice requirements, the franchisor may terminate only for "good cause," as defined by the statute. ${ }^{58}$ Thus, the franchisor inay terminate only (1) if the franchisee fails to comply with a franchise provision that is "both reasonable and of material significance to the franchise relationship";59 (2) if the franchisee fails to exert

54. Because of congressional concerns about fifth amendment due process challenges, the termimation provisions of the Act do not apply to franchises entered into before the effective date of the statute. H.R. REP. No. 161, at 22. The Act does apply, however, to a failure to renew a franchise relationship entered into prior to the Act's passage.

If the provisions of this title were made applicable to franchise terminations, in the case of franchises entered into prior to date of enactunent of the legislation, it might be contended by the franchisor that the hinitations imposed by the legislation upon termination rights such franchisor may have under the franehise agreement dcnies [sic] him the benefit of a valuable property right and thereby amounts [sic] to a "taking" of property without payment of just compensation. The legislation, therefore, contemplates that the franchisor may, if permitted to do so by applicable State law or the provisions of the franchise agreeınent, terminate a franchise entered into prior to the date of enactunent of the legislation (and not renewed thereafter) without regard to the provisions of this title once such a termination is effected. In such a case, the franchisor is required to rcnew the "franchise relationship" unless a grounds for non-renewal exists under this title.

Id. Although the franchisor must renew the franchise agreement in this situation, he may bargain (in good faith) for new terms or conditions. By allowing the franchisors to bargain for new terms prior to renewing a franchise agreement, Congress sought to avoid the charge that the renewal requirement is a taking of the franchisor's property without compensation. Id. See 15 U.S.C.A. $\S 2802$ (a) (West Supp. 1979).

55. 15 U.S.C.A. $\$ 2804$ (West Supp. 1979). If the franclisor is withdrawing froin the economic region, he must give 180 days' notice and also notify the governor of the affected state. A shorter notice period is permitted if "reasonable." Id. $\$ 2804(\mathrm{~b})(1)$.

56. See, e.g., 15 U.S.C.A. \& 2802(b)(2)(A) (West Supp. 1979).

57. H.R. REP. No. 161, at 24. The oil companies argued unsuccessfully against the inclusion of this provision: "By charging franchisors with constructive knowledge lof a reason to tcrminate the franchise]-or what they would have known had they attempled to find out-and providing a short tine fraine within which the franchisor may act, this provision will make franchise termination extremely difficult, even when there is good cause." Hearings 219-20 (statement of Douglas G. Linn).

58. 15 U.S.C.A. $\$ 2802$ (West Supp. 1979).

59. Id. $\$ 2802(\mathrm{~b})(2)(\mathrm{A})$. In Malone v. Crown Cent. Petroleum Corp., 474 F. Supp. 306 (D. Md. 1979), the court denied a motion for a preliminary injunction brought by the franchisee, Malone, who had been terminated by Crown for failure to comply with a "minimum gallonage" requirement. The Malone court found both that the "'minimum gallonage' requirement was an 
good faith efforts to carry out the provisions of the franchise; 60 (3) if an event occurs that is relevant to the franchise relationship and that makes termination "reasonable";61 (4) if the franchisor reaches a written agreement with the franchisee to end the franchise relationship;62 or (5) if the franchisor is withdrawing from the economic region. ${ }^{63}$

integral and a reasonable part of Crown's marketing strategy," id. at 310, and that Malone's failure to comply-or even to make a good faith effort to comply-rendered termination by Crown permissible under section 2802(b)(2)(A) of the Act. $474 \mathrm{~F}$. Supp. at 311-12.

60. 15 U.S.C.A. $\$ 2802$ (b)(2)(B) (West Supp. 1979). The franchisor may terminate for this reason only if the franchisee has been apprised in writing of his failures and has been given a reasonable opportunity to correct them. Id. $\$ 2802$ (b)(2)(B)(i); H.R. REP. No. 161, at 24.

61. 15 U.S.C.A. $\$ 2802$ (b)(2)(C) (West Supp. 1979). Another section of Title I further defines this rather broad provision by providing a list of events that would make termination "reasonable." These events include fraud or criminal misconduct by the franchisee, the declaration of bankruptcy by the franchisee, or the loss of title to the leasehold through exercise of eminent domam. Id. § 2802(c). The legislative history of the Act suggests that this statutory listing "is not exclusive. . . . However, the enumerated list is intended to provide a measure of Congressional intent with respect to the meaning of this statutory standard." H.R. REP. No. 161, at 28. Thus, a court can determime that an event not listed is a "reasonable" ground for termination, but should "carefully scrutmize" the situation before reaching that conclusion. Id.

62. 15 U.S.C.A. $\S 2802(b)(2)(D)$ (West Supp. 1979). The agreement to terminate must be entered into no earlier than 180 days prior to the date of termination. This is to prevent the franchisor from forcing the franchisee to sign a inutual termmation agreement at the inception of the franchise relationship. H.R. REP. No. 161, at 24.

63. 15 U.S.C.A. $\$ 2802(\mathrm{~b})(2)(E)$ (West Supp. 1979). This provision apphies to franchisors who are withdrawing their marketing operations from an entire geographic marketing area both in good faith and in the normal course of busmess. For purposes of this provision a "relevant geographic marketing area' [is] a State or a standard metropolitan statistical area as periodically established by the Office of Management and Budget." Id. §2801(16). Under section 2802(b)(2)(E), if a franchisor termmates or fails to renew because he is withdrawing from the marketing area, he unust give the franchisee a right of first refusal on the sale of the leased inarketing premises. If the franchisor sells the property to a third party, the third party inust offer the franchisee a franchise on terms similar to other franchise agreements made by the new franchisor in the area. Id. $\S 2802(b)(2)(E)$. This requirement could act as a restraint on alienation since the franchise seems almost to "run with the land."

The provisions of section 2802(b)(2)(E) apply equally to franchise agreements that were entered into prior to the effective date of the Act and to agreements entered into after that date that offered or granted a term of three years or longer. Froun these provisions alone it would appear that a franchise agreement entered into after the effective date of the Act and renewable yearly would not be susceptible to termination or nonrenewal by reason of withdrawal from the geographic market area. The Act, however, provides im section 2803(b)(3) a mechanism known as an "interim franchise." A franchisor who qualifies for termination or nonrenewal under section 2802(b)(2)(E), but who does not meet the three-year term requirement, can refuse to renew the original franchise and enter instead into an interim franchise. When the interim franchise expires the franchisor is freed from the franchise relationship. The duration of the interim franchise must be "conspicuously" set out in writing. Id. §2803(b)(3)(D); see H.R. REP. No. 161, at 29.

These complicated statutory provisions apparently are designed to force those franchisors who have entered into franchise agreements with terms of less than three years to renew the franchise agreement at least once before they nay withdraw from the region for econounic reasons. The requirement reflects congressional fear that franchisors could use spurious "business 
Each of the above grounds for termination under the Act also applies to failures to renew a franchise agreement when it expires. In addition, under statutory provisions that apply only to nonrenewals, ${ }^{64}$ the franchisor may refuse to renew (1) if the franchisor and franchisee fail to agree on terms for the new contract, provided that the franchisor bargams im good faith; 65 (2) if the franchisor receives "numerous bona fide complaimts" about the franchisee's operation and the franchisee is both apprised of the complaimts and given an opportunity to corrcct deficiencies; ${ }^{66}(3)$ if the franchisee fails to operate clean and safe premises-again, provided that the franchisee is given an opportunity to inend his ways; ${ }^{67}$ or (4) if the franchisor (subject to certam franchise term restrictions) decides "in good faith and in the normal course of business" to alter, convert, or sell the service station premises or if it is "uncconomical" for the franchisor to contimue the franchise relationship. ${ }^{68}$

reasons" as a means of avoiding the Act's requireınents. The fairness and economic efficiency of this method, however, is questionable. See notes 114-35 infra and accompanying text.

A new franchisor wishing to avoid the entanglement of the Act can enter into a "trial franchise" agreement for one year. 15 U.S.C.A. \& 2803(b)(1) (West Supp. 1979). A trial franchise is not subject to any of the nonrenewal provisions of the Act, although proper notice of nonrenewal is required. $I d . \S 2803$ (c)(1). If at the end of the trial franchise the franchisor is not completely certam that he wants an extended relationship with his franchisee, he is well-advised to withdraw quickly. Once a trial franchise is extended past a year it becomes a conventional franchise, thus falling under the Act's tight control. H.R. REP. No. 161, at 29. See Wojciechowski v. Amoco Oil Co., 483 F. Supp. 109 (E.D. Wis. 1980), in which the court held a trial franchise invalid because of a technical violation of the Act's notice provisions. In so holding, the court stated: "In effect, the Court is depriving the defendant of the right to treat plaintiff as a "trial franchise.' Therefore, defendant must coinply with the [Act's nonrenewal provisions] before the nonrenewal can take effect." Id. at 114.

64. 15 U.S.C.A. \& 2802(b)(3) (West Supp. 1979).

65. Id. § 2802(b)(3)(A).

66. Id. $\S 2802(\mathrm{~b})(3)(B)$. See Frisard v. Texaco Inc., 460 F. Supp. 1094 (E.D. La. 1978).

67. 15 U.S.C.A. \& 2802(b)(3)(C) (West Supp. 1979). See Saad v. Shell Oil Co., 460 F. Supp. 114 (E.D. Mich. 1978).

68. 15 U.S.C.A. $\S 2802$ (b)(3)(D) (West Supp. 1979). The determination by the franchisor that continuation of the franchise would be "uneconomical" cannot be based solely on the fact that it would be more profitable for the franchisor to operate the service station himself. See H.R. REP. No. 161, at 27. The legislative history also states that in making the deternination that a franchise continuation would be uneconomical, the court should "avoid judicial scrutiny of the business judgment [of the franchisor]." Id. 28. It is difficult to see, however, how a court faced with a Title I termination case can avoid examining the context of the business relationships of the parties. See, e.g., Malone v. Crown Cent. Petroleum Corp., 474 F. Supp. 306, 310 (D. Md. 1979) (the court considered a franchisor's narket position in reaching its decision in a Title I case). See also notes 114-35 infra and accompanying text.

A franchise agreement entered into before the effective date of the Act (June 19, 1978) is subject to the nonrenewal provisions in section 2802(b)(3)(D) only if the unexpired term of the franchise-as of the Act's date of enactment-was three years or longer. If the franchise agree- 


\section{B. Actions Under the Petroleum Marketing Practices Act.}

If a termination or nonrenewal does occur, and the franchisee beheves that the franchisor has not complied with the Act, the statute authorizes the franchisee to bring a suit in federal court. ${ }^{69}$ The plaintiff-franchisee may be entitled to a preliminary injunction to inamtain the status quo until the resolution of the issue. ${ }^{70}$ If the franchisee prevails on the merits, he can obtain a pernnanent injunction ${ }^{71}$ against termination or nonrenewal and can obtain actual and punitive dainages. $^{72}$

ment was entered into or renewed on or after the date of the Act, section 2802(b)(3)(D) applies only if the franchisee was offered or granted a franchise term of three years or longer.

Despite the similarity of the three-year term requirement under this section and the threeyear term requirement under section $2802(b)(2)(E)$, there is no provision under section 2802(b)(3)(D) for an "interim franchise." See note 63 supra. The reason for this inconsistency is unclear. This difference may effectively disallow all nonrenewals of year-to-year franchise agreements under section $2802(\mathrm{~b})(3)(\mathrm{D})$.

69. 15 U.S.C.A. $\$ 2805$ (West Supp. 1979). The action can also be brought in state court. See Ted's Tire Serv. Inc. v. Chevron U.S.A. Inc., 470 F. Supp. 163, 165 (D. Conn. 1979).

70. 15 U.S.C.A. $\$ 2805$ (b) (West Supp. 1979). The court may grant a temporary injunction if the franchisee proves actual termination or nonrenewal, shows that there are "sufficiently serious questions going to the merits to make . . . a fair ground for litigation," and denonstrates that the hardships imposed on the franchisor if temporary relief is granted will be less than the hardships on the franchisee if the relief is not granted. $I d . \$ 2805(\mathrm{~b})(2)$. The court is not required to exercise its equity powers if the franchisee waits more than 90 days after notice of termination or nonrenewal to bring an action. Id. $\$ 2805$ (b)(4)(A); see, e.g., Sachi v. Mobil Oil Corp., 1980-1 TRADE CAs. (CCH) I] 63,044 (E.D.N.Y. 1979).

The majority of the cases arising under the Act to date have involved inotions for preliminary mjunctions. The courts liave recognized that "the Act sets forth a preliminary injunction standard that is significantly more lenient than the general equity standards for prehminary injunctions." Gilderhus v. Amoco Oil Co., 470 F. Supp. 1302, 1303 (D. Minn. 1979). See, e.g., Sexe v. Husky Oil Co., 475 F. Supp. 135 (D. Mont. 1979) (termination by Husky because of a dispute over rental policies raised a question on the merits sufficient to warrant issuance of a temporary injunction); cf. Pearman v. Texaco Inc., 480 F. Supp. 767 (W.D. Mo. 1979) (termination by Texaco because of a dealer's refusal to pay a rental imcrease held insufficient to warrant issuance of a temporary injunction). See also Marimi v. Atlantic Richfield Co., 475 F. Supp. 142 (D.N.J. 1979) (temporary injunction granted because of evidence of coercion by a franchisor); Saad v. Shell Oil Co., $460 \mathrm{~F}$. Supp. 114, 117 (E.D. Mich. 1978).

71. 15 U.S.C.A. $\$ 2805$ (b)(1) (West Supp. 1979).

72. 15 U.S.C.A. $\$ 2805$ (d) (West Supp. 1979). "If the franchisee prevails in any action under [the Act], such franchisee shall be entitled . . . consistent with the Federal Rules of Civil Procedure, to actual damages . . . " Id. $\$ 2805(\mathrm{~d})(1)(\mathrm{A})$. Exeinplary dainages are available when the court determines that the franchisor has acted in "wilful disregard" of the requirements of the Act. Id. $\$ 2805$ (d)(1)(B). Cases decided under the federal Automobile Dealers' Day in Court Act, 15 U.S.C. $\$ \S 1221-1225$ (1976), may provide guidance in determining damages under Title I of the Petroleum Marketing Practices Act. Under the federal Automobile Act courts have allowed recovery for loss of future profits in franchise termmation cases. See Randy's Studebaker Sales, Inc. v. Nissan Motor Corp., 533 F.2d 510, 518 (10th Cir. 1976). Furthermore, one court has allowed the use of actuarial tables showing the dealer's lifespan in order to determine damages, if the jury believes that the franchise would have been renewable throughout the dealer's lifetime. Garvin v. American Motors Sales Corp., 202 F. Supp. 667, 672 (W.D. Pa. 1962), rev'd on other grounds, 318 
In a suit under the Act, the franchisee's initial burden is to show only a prospective or actual termination or nonrenewal. The burden then shifts to the franchisor to prove compliance with the requirements of the Act. ${ }^{73}$ The statute thus establishes a presumption that any termination or nonrenewal is illegal and forces the franchisor to prove that his action falls within one of the defined exceptions to the "no termination" rule.74

One unusual section of the Act provides a built-in equitable defense for the franchisor in a suit brought under the statute. ${ }^{75}$ If the franchisor fails to renew a relationship for reasons such as a desire to alter, convert, or sell the premises or a desire to withdraw from the econonic region, but he fails to satisfy fully the requirenents of the statute for nonrenewals, ${ }^{76}$ the court inay not award the franchisee per1nanent injunctive rehef. ${ }^{77}$ Nevertheless, the franchisee may be entitled to actual damages as a result of the nonrenewal. ${ }^{78}$ This provision apparently is designed to provide rehef to franchisors whose economic circuinstances inake nonrenewal inuperative. The right of the franchisee to actual damages is thought adequate to protect his interests in this situation. ${ }^{79}$

\section{Problems in Judicial Interpretation of the Petroleum Marketing Practices ACT}

Although Title I of the Act attempts to describe explicitly the rights and obligations of the franchisor in a termination situation, inuch is necessarily left to judicial interpretation. In fact, the legislative history of the Act indicates that Congress deliberately left soine of the Title I provisions vague to allow for judicial consideration of all facts

F.2d 518 (3d Cir. 1963). See also Shor-Line Rambler, Inc. v. American Motors Sales Corp., 543 F.2d 601 (7th Cir. 1976) (jury award of ten years' future profits upheld in a franchise termination case); American Motors Sales Corp. v. Semke, 384 F.2d 192, 200 (10th Cir. 1967) (damages for wrongful termination "must include the amount of money that the dealer could have obtained in the future from the profits from his franchise").

73. 15 U.S.C.A. $\$ 2805$ (c) (West Supp. 1979). The oil companies strongly opposed this provision of the Act. They contended that the franchisee should bear the burden of coming forward with the evidence showing that the termination or nonrenewal violated the statute. Placing thc burden on the defendant to prove a lawful termmation is, according to one oil company, "contrary to our systein of laws." Hearings 220 (statement of Douglas G. Linn).

74. I5 U.S.C.A. $\$ 2802$ (a) (West Supp. 1979).

75. Id. $\$ 2805(\mathrm{e})(\mathrm{l})$.

76. The three-year term, see note 63 supra, is an example of one of these requirements.

77. 15 U.S.C.A. \$2805(e)(1) (West Supp. 1979); see H.R. REP. No. 161, at 31-32. The franchisor must be acting in good faith in order to receive the benefit of this provision. 15 U.S.C.A. $\$ 2805(\mathrm{e})(1)(\mathrm{A})$ (West Supp. 1979).

78. 15 U.S.C.A. § 2805(e)(2) (West Supp. 1979).

79. See note 72 supra. 
relevant to the Act's interpretation. ${ }^{80}$ For example, the courts enjoy great discretion in deciding whether a termination was due to "[a] failure by the franchisee to exert good faith efforts to carry out the provisions of the franchise" 81 or due to the "occurrence of an event which is relevant to the franchise relationship." 82

In exercismg this discretion, the courts should consider two major factors. First, they should look to decisions under the trademark laws and consider whether a strict interpretation of the Act in favor of the franchisee will violate the spirit of trademark law, which requires franchisors to maintain "quahty control" over their franchisees. ${ }^{83}$ Second, the courts should consider the statute in light of the economic and commercial realities that influenced the actions of the parties. ${ }^{84}$ Consideration of the commercial setting of the parties' franchise relationship can be especially crucial to a just result because of the unpredictability of the present gasoline market. Ultimately, resolution of Title I termination cases necessarily involves consideration of the interests of the franchisee, the franchisor, and consumers. ${ }^{85}$

\section{A. The Petroleum Marketing Practices Act's Relationship to Trademark Law.}

The Petroleum Marketimg Practices Act defines a "franchise" as a contract between an oil supplier and an oil dealer in which the oil supplier "authorizes or permits [the dealer] to use . . . a trademark which is owned or controlled" by the suppher. ${ }^{86}$ It is appropriate that the

80. S. REP. No. 731, supra note 9, at 38, [1978] U.S. CODE CoNG. \& AD. News at 896. "[T] he legislation leaves to the courts the task of resorting to traditional principles of equity to maximize attainment of the competing statutory objectives . . . Id. 43 , U.S. CoDE CONG. \& AD. NEwS at 901.

81. 15 U.S.C.A. $\$ 2802(b)(2)(B)$ (West Supp. 1979).

82. Id. $\$ 2802(\mathrm{~b})(2)(\mathrm{C})$. One exainple of sensible use of judicial discretion under this section of Title I is Lanhain v. Ainoco Oil Co., 481 F. Supp. 405 (D. Md. 1979). In Lanham the court held that the death of the franchisce was adequate grounds for terminating the franchise. The court found that although death was not "expressly cited" as grounds for termination under the Act, "the clear inplication" of section 2802(b)(2)(C) was to allow termination in this type of situation. 481 F. Supp. at 407.

83. See notes $86-113$ infra and accompanying text.

84. See notes 114-34 infra and accompanying text.

85. During the hearings on the Act, Representative Clarence Brown of Ohio summed up the difficult balancing of interests involved im franchise regulation:

I neither want to write a bill that is going to inake it possible for the major oil companies to . . . totally run the gasoline market; nor do I want to put something into law that tilts the laws about property so far in favor of the franchisee that he is in a position to run the world on his own; nor do I want to leave out somebody who provides the consumer with a considerable advantage in price, because we have a lot more consumers than . . . dealers.

Hearings 191.

86. 15 U.S.C.A. $\$ 2801(1)(A)$ (West Supp. 1979). 
statute defines a franchise in terms of a license to use a trademark because "[t]he central element of most franchises . . . is a license granted to the franchisee to use the franchisor's trademark . . . . This right to do business under a well known brand name is usually the single most valuable asset acquired by a franchisee . . . ."87

The trademark is also an integral part of the "joimt venture" model of franchising. ${ }^{88}$ The franchisor provides the franchisee witli the nationally known name and products that attract business to the franchisee's operation. In return, the franchisee, through good service to the public, increases the "good will" associated witl the trademark. ${ }^{89}$ Thus the franchisee's contribution to the intangible good will of the trademark gives him a "vested property" 90 right in the mark and forms the basis for requiring good cause before terminating his interest in the franchise.

Given this strong relationship between trademark rights and franchising, the Lanham Act ${ }^{11}$-whicl1 regulates trademark and tradename rights-may play a role in how courts resolve cases brought under Title I of the Petroleum Marketing Practices Act. Courts have long held that the licensor of a trademark has a duty under the Lanham Act to control the quality of his mark so that the public will not be deceived:

If the owner of a trademark wants to license the use thereof to another and still retain as his own the enjoyment of the rights stemming therefrom, he must do so in such a way that he maimtaims sufficient control over the nature and quahity of the finished product, over the activities of the licensee, as will enable the licensor to sustam his

87. J. MCCARThy, TRADEMARKS AND UNFAIR COMPETITION § 18:20, at 644 (1973) (quoting Handler, Franchising and Business Independence, in THE Economics OF ANTITRUST 153 (R. Low ed. 1968) (citations omitted)). " The cornerstone of a franchise system must be the trademark or trade name of the product.' Many franchise contracts can be legally characterized as a skeleton of a trademark license fleshed out with many duties and restrictions imposed upon the franchisee." J. MCCARTHY, supra, at 644 (quoting Susser v. Carvel Corp., 206 F. Supp. 636, 640 (S.D.N.Y. 1962), aff'd, 332 F.2d 505 (2d Cir. 1964)). Another observer has noted:

While franchises defy placement into the conventional categories of commercial relationships, they may be readily identified by the central role played by the franchisor's trademark .... Indeed, a franchise may be fairly defined as a license to use the franchisor's identifymg marks as a means of securing the economics of its national advertising and consumer identification-the franchisor's accumulated custouner good will.

Note, supra note 3, at 1488.

88. See notes 26-31 supra and accompanying text.

89. Each franchisee is a part of a conplex marketing system in which the public is encouraged to make its choice as to filling stations to patronize based on the personal service facilities and the cleanliness of these facilities. A breakdown in any one facility can seriously affect others in the system.

Saad v. Shell Oil Co., 460 F. Supp. 114, 117 (E.D. Mich. 1978).

90. Brown \& Cohen, supra note 26, at 1161.

91. 15 U.S.C. $\S \S 1115-1127$ (1976). 
original position of guarantor to the public that the goods now bearing the trademark are of the same nature and quality as were the goods bearing the trademark before the licensing . . . .92

If the franchisor, as trademark owner, fails to exercise proper control over the licensee of his trademark, the courts may say that the franchisor has abandoned" 93 his mark and lias lost "the . . . exclusive riglit to use the registered mark in commerce . . . ."94

Not surprisingly, some courts liave noticed a tension between the "quality control" requirements of the trademark laws and the "good cause" termmation statutes, which tend to lessen the ability of the franchisor to influence the actions of his franchisees. Marinello $v$. Shell Oil Co. ${ }^{95}$ illustrates judicial recognition of this problein. In Marinello, the plaintiff brought an action in federal district court under a New Jersey franchise termination statute ${ }^{96}$ that was similar to Title I of the Petroleum Marketmg Practices Act. The Marinello court first determined that "[ $t]$ he Lanham Act, which constitutes the federal statutory law of trademarks, [was] properly at issue . . . ."97 The court went on to find that the New Jersey Supreme Court's rule announced in a related case, Shell Oil Co. v. Marinello,"98 requirmg "good cause" for franchise termination, was "invalid and inapplicable," requirement of "good cause" before termination had the effect of "whittl[ing] the rights of the owner of a federally registered trademark and correspondingly enlarg[mg] the rights of a licensee in such a trademark . . . ."100 Tlie state "good cause" regulation "collide[d] witl the Lanham Act's preemptive grant to its owner of total control of a federally registered trademark."101 The Marinello court therefore lield that

92. Morse-Starrett Prods. Co. v. Steccone, 86 F. Supp. 796, 804 (N.D. Cal. 1949); see Denison Mattress Factory v. Spring-Air Co., 308 F.2d 403, 409 (5th Cir. 1962); Dawn Donut Co. v. Hart's Food Stores, Inc., 267 F.2d 358, 366 (2d Cir. 1959); J. MCCARTHY, supra note 87, § 18:16.

93. 15 U.S.C. $\$ 1115$ (1976).

94. Id. $\$ 1115(\mathrm{~b})$. The amount of control the licensor of a mark must maintain over his licensee in order to avoid abandonment of the mark is not clear, for "[t]he courts have been hopelessly mconsistent in defining how much is needed to satisfy the requirement of quality control over trademark licensees." J. MCCARTHY, supra note 87 , § 18:17, at 639.

95. 368 F. Supp. 1401 (D.N.J. 1974), rev'd, 511 F.2d 853 (3d Cir. 1975).

96. N.J. Stat. ANN. $\S \S 56: 10-1$ to -12 (West Supp. 1977). See note 99 infra.

97. $368 \mathrm{~F}$. Supp. at 1405 .

98. 63 N.J. 402, 307 A.2d 598 (1973), cert. denied, 415 U.S. 920 (1974).

99. 368 F. Supp. at 1407. Technically, the series of cases involving Shell and Marinello did not involve the New Jersey Franchise Practice Act since that act was not im effect at the time of the litigation. Nevertheless, the New Jersey act clearly served as a basis for decision in this line of cases since it "put into statutory form the extant public policy of [the] State." Shell Oil Co. v. Marinello, 63 N.J. at 409, 307 A.2d at 602.

100. 368 F. Supp. at 1407.

101. Id. 
under the supremacy clause ${ }^{102}$ the offending state law "must give way to federal" law. ${ }^{103}$

The court of appeals reversed, ${ }^{104}$ finding that the Lanham Act regulated trademarks only to the extent necessary to prevent the deception of the public and to protect the investor. The court then stated that "[n]o deception of the public is suggested and no dilution of Shell's investment in its trademark is alleged to have occurred . . .."105 Thus the court held that the state good cause termination requirements in question were not preempted by the Lanham Act. ${ }^{106}$

The district court and court of appeals opmions in Marinello demonstrate the tension between trademark regulation and franchise regulation. The Petroleum Marketing Practices Act gives the franchisee security by making it difficult for the franchisor to terminate or fail to renew the franchise relationship. The Lanham Act, on the other hand, imposes a duty on the franchisor to maintain control over the licensees of his mark, so that the mark will contmue to represent the quality of goods and services that the public has come to expect. Because even one low-quality station can liurt the reputation of the entire trademark chain, franchisors have a strong mcentive to control the quality of each of their stations. ${ }^{107}$

While the principle of quality control is based on trademark law, any erosion of the principle has effects beyond simply decreasing the significance of trademarks. If the Petroleum Marketing Practices Act prevents legitimate dealer quahty control requireinents by making it more difficult and costly for franchisors to terininate recalcitrant franchisees, consumers could be hurt by the reduction in the quality of service. 108 Consider the hypothetical case of a gas station dealer who dilutes his gasoline with water. The oil company franchisor attempts to

102. U.S. CoNST. art. VI, cl. 2.

103. 368 F. Supp. at 1407.

104. Marinello v. Shell Oil Co., 511 F.2d 853 (3d Cir. 1975).

105. Id. at 858 .

106. Id. For an analysis that agrees with the decision of the court of appeals see Comment, Federal District Court Declares New Jersey Franchise Practices Act to be an Unconstitutional Regulation of Trademark in Conflict with the Lanham Act, 6 RuT.-CAM. L.J. 155 (1974).

Of course, preemption is not a factor in the relationship between the Petroleum Marketing Practices Act and the Lanham Act since both are federal statutes. Nevertheless, the analysis used by the district court in Marinello to find preemption of the state act by the Lanham Act indicates the conflict between the goals of the Petroleun Marketing Practices Act and those of the Lanham Act.

107. See note 89 supra and accompanying text.

108. See Jordan 839. Not all franchisees given greater freedom of conduct in the franchise relationship will autonatically respond by reducing the quality of service, for the franchisee also has an economic interest in seeing business imcrease. Nevertheless, the force of the "quality con- 
terminate the dealer, ${ }^{109}$ and the dealer brings an action under the Act, claiming that the franchisor gave the dealer only eighty-five days notice of the termination rather than the required ninety days. ${ }^{\text {to }}$ A court applying the statute strictly would probably find for the dealer because of the franchisor's five-day delinquency in notification. A superior approach would be to look beyond the dictates of the statute and to consider as well the rights and duties of the franchisor under the Lanham Act $^{111}$ to control the quality of the gasoline dispensed by its franchisees. ${ }^{12}$ A court should also consider the right of consumers to purchase undiluted gasoline.

In summary, courts adjudicating claims by franchisees arising under Title I of the Petroleum Marketing Practices Act should exercise the discretion granted in the Act $^{113}$ and should atteinpt to balance the competing statutory objectives of the trademark and franchise laws. In so doing, the courts should look not only at Title l's reinedial purpose, but also at the right of the franchisor to control the trademark and at the need for consumer protection.

\section{B. The Petroleum Marketing Practices Act and the UCC "Commercial Setting" Standard.}

The same discretion to balance coinpeting interests ${ }^{114}$ that perunits

trol" argument is strong because even a few bad franchises can hurt the entire trademark chain. This is especially true of smaller chams that serve only local or regional customers.

One commentator has argued that "franchisees who want to be made secure agamst termination may find that the demand for this security means the end of the system withm which they operate." Jordan 840 . Major oil franchisors, faced with increasing regulation of the franchise relationship, may respond by establishing more company-owned stations. This process, called "forward integration," could drastically reduce the number of service station franchises available.

Some states are responding to this situation by passing "divorcement" statutes that prohibit the large oil companies from owning their own service station outlets. The Supreme Court recently upheld Maryland's divorcement statute in Exxon Corp. v. Governor of Md., 437 U.S. 117 (1978). See generally Comment, State Gasoline Divorcement Statutes: Legal and Economic Implications, 28 CATH. U.L. Rev. 511 (1979).

109. The franchisor's argument for termination under the Act would probably be that the dealer had engaged im "fraud or crimmal misconduct . . . [that is] relevant to the operation of the marketing premises." 15 U.S.C.A. $\$ 2802(c)(1)$ (West Supp. 1979).

110. Id. $\$ 2804(\mathrm{a})(2)$. A court could find the 85-day notice "reasonable" and deein it adequate under the statute. Id. $\S 2804(b)(1)$. See, e.g., Frisard v. Texaco Inc., 460 F. Supp. 1094, 1101 (E.D. La. 1978) (the Act's notice requirements need not be measured with "mathematical certainty"). But see Blankenship v. Atlantic-Rich field Co., 478 F. Supp. 1016, 1018 (D. Or. 1979) (90day notice requirement held a mandatory prerequisite to termmation).

111. See text accompanying notes 91-94 supra.

112. Although the franchisor could conceivably renotify the recalcitrant dealer and attempt to termmate his dealership again, the lengthy delay inherent in that course of action makes it an undesirable alternative.

113. See notes 80-82 supra and accompanying text.

114. See notes 80-82 supra and accoinpanying text. 
the courts to consider trademark principles in Title I cases ${ }^{15}$ also allows thein to consider the commercial setting of the particular franchise relationship. ${ }^{116}$ The courts should recognize the many complex business and econoinic forces that affect both the terms of a franchise relationship and termination and nonrenewal decisions.

In analyzing the importance of the commercial setting in a termination case, the courts should look to an established body of law for guidance. The Uniforin Commercial Code's unconscionability standards ${ }^{117}$ provide such guidance to courts faced with Title I termination claims. Resort to the Code for aid in interpreting Title I cases is logical since the Act "may . . . merely have federalized the unconscionability problem between dealers and suppliers."118 Section 2-302(2) of the Uniform Commerical Code provides that "the parties shall be afforded a reasonable opportunity to present evidence as to . . commercial setting, purpose and effect to aid the court in making the determmation" of unconscionability. ${ }^{119}$ Similarly, before a court concludes that a termination or nonrenewal of a franchise relationship is unlawful, it should consider the commercial setting of the relationship.

A case illustrating the use of section 2-302(2) is Ashland Oil, Inc. v. Donahue. ${ }^{120}$ The plaintiff oil company, after invoking a ten-day termination clause, brought an unlawful detainer action agamst its dealerfranchisee to recover possession of service station property. The court first held that the lease and the franchise agreement between Ashland and Donahue should be read as one contract. ${ }^{121}$ The court went on to find the ten-day termmation clause in the agreement unconscion-

115. See notes 86-113 supra and accompanying text.

116. "[C]ourts ought to look closely at the realities of the marketplace" in deciding franchise termination cases. Jordan 856. "Particularly important is that legislation dealing with [franchise terminations] recognize the inportance of providing adequate flexibility so that franchisors may initiate changes in their inarketing activities to respond to changing market conditions and consumer preferences." S. REP. No. 731, supra note 9, at 19, [1978] U.S. CODE CONG. \& AD. NEws at 877.

117. U.C.C. $\$ 2-302$ provides:

(1) If the court as a matter of law finds the contract or any clause of the contract to have been unconscionable at the time it was made the court may refuse to enforce the contract, or it may enforce the reinainder of the contract without the unconscionable clause, or it may so limit the application of any unconscionable clause as to avoid any unconscionable result.

(2) When it is clained or appears to the court that the contract or any clause thereof inay be unconscionable the parties sliall be afforded a reasonable opportunity to present evidence as to its commercial setting, purpose and cffect to aid the court in making the determination.

118. Jordan 825 n. 86 .

119. U.C.C. \& 2-302(2) (emphasis added).

120. 223 S.E. $2 d 433$ (W. Va. 1976).

121. Id. at 437. 
able. ${ }^{122}$ Nevertheless, the court remanded the case for the trial court to receive evidence "regarding the commercial setting, purpose and effect of the transaction" before determining the ultimate resolution of the case. ${ }^{123}$

Other courts have considered the commercial setting in deciding cases involving franchise relationships. ${ }^{124}$ In Tulowitzki v. Atlantic Richfield Co. ${ }^{125}$ the Supreme Court of Delaware upheld Atlantic Richfield's termmation of plaintiff Tulowitzki's franchise. The court apphed a "business-practices-of-the-community test [that] asks whether the terms [of the franchise agreement] are so extreine as to appear unconscionable according to the mores and business practices of the time and place."126 The Tulowitzki court found that the agreement in question was consistent with trade business practices and upheld the termination. ${ }^{127}$

Two early decisions under Title I of the Petroleum Marketing Practices Act suggest that courts faced with termination claims under the Act will also consider commercial setting. In Malone v. Crown Central Petroleum Corp. ${ }^{128}$ the court held that a "minimum gallonage" requirement in a franchise agreement was "both an integral and a reasonable part of [the franchisor's] marketing strategy" 129 and that the failure of the franchisee to make "good faith efforts" to meet the requirement justified termination under the Act. ${ }^{130}$ Similarly, the court

122. Id. at 440 .

123. Id.

124. See Posttape Assoc. v. Eastman Kodak Co., 450 F. Supp. 407, 412 (E.D. Pa. 1978); Central Ohio Co-Operative Milk Producers, lnc. v. Rowland, 29 Ohio App. 2d 236, 239-40, 281 N.E.2d 42, 44 (1972). In Raybond Elecs., Inc. v. Glen-Mar Door Mfg. Co., 22 Ariz. App. 409, 528 P.2d 160 (1974), the court stated that courts must "have the widest latitude in hearing evidence on the issue of commercial setting in cases where unconscionability was claimed . . . I Id. at 416 , 528 P.2d at 167 .

125. 396 A.2d 956 (Del. 1978).

126. Id. at 960; see Gordon v. Crown Cent. Petroleum Corp., 423 F. Supp. 58, 61-62 (N.D. Ga.), aff'd, 564 F.2d 413 (5th Cir. 1977).

127. 396 A.2d at 962.

128. 474 F. Supp. 306 (D. Md. 1979).

129. Id. at 310 .

130. Id. at 310-11. The Malone court, however, adinonished the franchisor for tenninating a valued franchisee in this manner. Id. at 312. The decision implied that had Crown not been a small oil company - with a need to do high volume busmess-the result might have been differeut, again demonstrating the importance of commercial setting.

In Sachi v. Mobil Oil Corp., 1980-1 TRADE CAS. (CCH) I 63,044, at 77, 190 (E.D.N.Y. 1979), the court held that Mobil Oil's nonrenewal of a franchise relationship was valid because of the expiration of the underlying lease on the service station property. The court stated: "Congress plainly did not intend to restrict the prerogative of the franchisor to exercise legitimate, independ$e n t$ business judgment in arriving at a decision not to renew an underlying lease to the franchise premises." Id. at 77,194 (emphasis in original). Thus the Sachi court clearly recognized the need 
in Frisard v. Texaco Inc. ${ }^{131}$ found that Texaco's oral notices of unhealthy conditions to its franchisee were sufficient given the business setting surrounding the notices. ${ }^{132}$ The Frisard court held that the Petroleuin Marketing Practices Act's notice provisions did not need to be measured with "mathematical certainty" and therefore denied the franchisee's request for a preliminary injunction to stop Texaco from terminating the franchise relationship. ${ }^{133}$

The commercial setting factor may favor franchisees as well. The commercial settimg of a franchise relationship could persuade a court that a termination or failure to renew is illegal. ${ }^{134}$ Regardless of the outcolne of a termination case, the court will have an opportunity to reach a superior decision by considering the commercial setting of the franchise relationship.

\section{CONCLUSION}

Title I of the Petroleum Marketing Practices Act attempts to address the substantial problems caused by the imbalance between the power of franchisors and franchisees in service station franchise relationships. Although this intrusion of government regulation into a contractual business arrangement can be criticized, the prevailing view is that the franchisee needs statutory protection from unjust terminations. ${ }^{135}$ Despite technical faults, ${ }^{136}$ Title I should meet its primary goal by offering significant protection to franchisees. The critical element in the ultimate success of Title I, however, will be judicial recognition of the importance of economic and legal factors apart from those

to consider business setting in rendering a decision under Title I of the Act. See also Walters v. Chevron U.S.A., Inc., 476 F. Supp. 353, 357 (N.D. Ga. 1979).

131. 460 F. Supp. 1094 (E.D. La. 1978).

132. Plaintiff Frisard had argued that the Act required written notices of unhealthy conditions before a franchisor could initiate a termination or nonrenewal. Id. at 1098. The statute is not clear on this point, although written notice is explicitly required when actual termmation proceedings are begun. 15 U.S.C.A. $\$ 2804$ (c)(1) (West Supp. 1979).

133. 460 F. Supp. at 1101-02.

134. See Brown 669. Although the majority of early cases under the Act have been favorable to the franchisor, the franchisee has, nevertheless, prevailed on a number of occasions. For example, in Gilderhus v. Amoco Oil Co., 470 F. Supp. 1302 (D. Minn. 1979), the court granted the franchisee's request for a prehininary injunction to enjoin franchisor Amoco from terminating his franchise relationship. Amoco's attempt followed the discovery that Gilderhus had been buying oil products from another supplier. The court found that "the plaintiff has raised a substantial question as to whether Annoco's decision to terminate was an act of discrimination" and therefore issued the preliminary injunction. Id. at 1305. For other early decisions under the Act that were favorable to the franchisee, see note 70 supra.

135. See notes 26-3I supra and accoinpanying text.

136. See, for example, the inconsistency discussed in note 68 supra. 
found on the face of the statute. ${ }^{137}$ Regulation of the franchise relationship necessarily has an impact on three distinct groups-the franchisor, the franchisee, and consumers-and the interests of these groups are finely balanced. Interpretation of Title I solely in light of its remedial purpose is likely to upset this balance and produce a "no win" situation in which the franchisor, the consumer, and even the franchisee will suffer.

Timothy J. Corrigan

137. Again, it should be stressed that Congress intended the court to have wide discretion in deciding Title I cases. See notes 80-82 supra and accoinpanying text. 